\title{
Clinical efficacy of semiconductor laser-assisted minocycline in moderate-to-severe chronic periodontitis patients with type 2 diabetes mellitus
}

\author{
Ren Le, Zhang Zhe, Li Daxu, Deng Chunni, Tao Hong \\ Department of Stomatology, The First Affiliated Hospital, Medical School of Xi'an Jiaotong University, Xi'an, China
}

${ }^{*}$ For correspondence: Email: cb0756@163.com

Sent for review: 15 March 2018

Revised accepted: 23 May 2018

\begin{abstract}
Purpose: To study the clinical efficacy of semiconductor laser-assisted minocycline in the treatment of moderate-to-severe chronic periodontitis (CP) in type 2 diabetes mellitus (T2DM) patients.

Methods: A total of 109 cases of CP combined with T2DM and obesity admitted to The First Affiliated Hospital, Medical School of Xi'an Jiaotong University, Xi'an, China, from November 2016 to November 2017 were included in the study. Among them, 54 patients in the study group were treated with semiconductor laser-assisted minocycline, while 55 patients in the control group were treated with minocyclin injection. Periodontitis, blood glucose and blood lipid levels were compared between the two groups before and after treatment.

Results: Post-treatment (12 weeks), bleeding on probing, gingival index, periodontal probing depth $(P D)$, plaque index $(P L I)$, clinical attachment loss $(C A L)$, and sulcus bleeding index $(S B I)$ in the two groups of patients were significantly improved $(p<0.05)$. The levels of $P D, B O P, P L I$, and CAL in the positive SBI group (4.06 $\pm 0.25,20.37 \%, 0.50 \pm 0.28,3.42 \pm 0.27$, and 1.43 \pm 0.26 , respectively) were significantly lower than the corresponding levels in the control group $(p<0.05$. Fasting plasma glucose (FPG) and HbA1c for the two groups were significantly improved, when compared with values prior to treatment $(p<0.05)$, but there was no significant difference in FPG level between the two groups. Significantly lower $\mathrm{HbA1c}$ levels were found in the treatment group than in the control group ( $t=4.2360$, $p=0.0001$ ). Post-treatment, triglyceride (TG), total cholesterol (TC) and body mass index (BMI) did not improve significantly in the two groups, nor were there significant differences in these parameters before and after treatment ( $p>0.05)$.

Conclusion: Semiconductor laser-assisted minocycline is effective in treating moderate and severe chronic periodontitis patients with type 2 diabetes, and can improve blood glucose. However, its effect on body weight needs further studies.
\end{abstract}

Keywords: Semiconductor laser, Minocycline, Chronic periodontitis, Type 2 diabetes, Obesity

\begin{abstract}
This is an Open Access article that uses a funding model which does not charge readers or their institutions for access and distributed under the terms of the Creative Commons Attribution License (http://creativecommons.org/licenses/by/4.0) and the Budapest Open Access Initiative (http://www.budapestopenaccessinitiative.org/read), which permit unrestricted use, distribution, and reproduction in any medium, provided the original work is properly credited.

Tropical Journal of Pharmaceutical Research is indexed by Science Citation Index (SciSearch), Scopus, International Pharmaceutical Abstract, Chemical Abstracts, Embase, Index Copernicus, EBSCO, African Index Medicus, JournalSeek, Journal Citation Reports/Science Edition, Directory of Open Access Journals (DOAJ), African Journal Online, Bioline International, Open-J-Gate and Pharmacy Abstracts
\end{abstract}

\section{INTRODUCTION}

$\mathrm{CP}$ continuously destroys the periodontium under the effect of multiple factors and usually gives rise to loss of teeth at the last stage [1]. Previous studies demonstrated that CP is closely associated with (T2DM) [2,3]. In the clinics, it is considered that the two factors may interact. 
Chronic periodontitis increases levels of inflammatory factors and impedes glucose metabolism through insulin resistance (IR), thereby aggravating T2DM [4]. Type 2 diabetes mellitus impacts on oral flora, contributes to their attachment, and weakens the body's ability to fight infection, thereby exacerbating CP. Chronic periodontitis has become a major complication of DM [5].

Previous studies revealed that obese T2DM patients are at higher risk of CP [6]. However, clinical studies on these patients are few. In recent years, semiconductor laser has been used for the clinical treatment of CP. However, its therapeutic effect is in dispute. In the present study, a total of 109 CP patients with T2DM and obesity, admitted in our hospital from November 2016 to November 2017, were recruited for investigating the clinical efficacy of semiconductor laser-assisted minocycline therapy.

\section{EXPERIMENTAL}

\section{General characteristics of subjects}

A total of $109 \mathrm{CP}$ patients with T2DM and obesity, admitted in our hospital from November 2016 to November 2017 were the study participants. The inclusion criteria were: (1) eligibility for the diagnosis of chronic periodontitis [7]; eligibility for the diagnosis of type 2 diabetes mellitus (T2DM); (3) obesity with BMI > 28; (4) age > 18 years; (5) regular hypoglycemic treatment for diabetes for stable blood glucose control; and (6) signing of an informed consent. The exclusion criteria were: (1) remaining teeth < 20; (2) pregnant or lactating women; (3) periodontal therapy within three months before the study; and (4) intake of antibiotics within the previous one month. Based on the inclusion criteria, 109 CP patients with T2DM and obesity were enrolled in the study. All patients were divided into two groups, based on treatment methods, with 54 patients in the study group given semiconductor laser and minocycline, while 55 patients in the control group received minocycline alone. This research was approved by the Ethical Committee of Medical School of Xi'an Jiaotong University (approval no. 20171201) according to the Declaration of Helsinki promulgated in 1964 as amended in 1996 [8].

\section{Treatment}

All patients were educated on oral health, and all the affected teeth underwent periodontal nonsurgical treatments including subgingival scaling and root planning (SRP). After periodontal nonsurgical treatment, the control group was given periodontal pocket injection therapy with minocycline (Sunstar INC, H20150106), once a week, for 4 weeks. In addition to periodontal nonsurgical treatment and minocycline, the study group received auxiliary semiconductor laser (Sirona, Germany, wavelength $980 \mathrm{~nm}$, power 2 w), zig-zagged on periodontal pocket. Each observation point was exposed for $30 \mathrm{~s}$, and the second laser radiation therapy was implemented at week 5 after the first one.

\section{Measurement of clinical and biochemical parameters}

Blood samples were collected from all patients before treatment, and at week 12 after treatment to determine glycosylated hemoglobin $(\mathrm{HbA1c})$, triacylglycerol (TG), total cholesterol (TC) and fasting plasma glucose (FPG). Clinical attachment loss (CAL), probing depth (PD), bleeding on probing (BOP), gingival index (GI), plaque index (PLI), and sulcular bleeding index (SBI) were recorded before treatment, and at week 12 after treatment.

\section{Statistical analysis}

All data were analyzed by software SPSS 18.0. Measurement data such as GI and PD, were expressed as mean \pm standard deviation $(\bar{\chi} \pm$ $\mathrm{s})$, while enumeration data were expressed as number/ percentage ( $\mathrm{n} / \%)$. Student's $t$-test and $x^{2}$ test were used for the analysis of various data. Values of $p<0.05$ were taken as indicative of significant difference between the effect of semiconductor laser-assisted minocycline treatment and the injection of minocycline alone.

\section{RESULTS}

\section{Characteristics of subjects}

The clinical data of two groups are shown in Table 1. There are no differences between the characteristics of two groups $(p>0.05)$.

\section{BOP, GI and PD indices}

At week 12 after treatment, there were significant improvements in BOP, GI and PD in both groups $(p<0.05)$, but the treatment group had much lower PD and BOP occurrence (4.06 \pm 0.25 and $20.37 \%$, respectively), when compared to the control group (4.23 $\pm 0.31, p=0.0148 ; 41.82 \%$, $p=0.0472$, respectively). However, there was no significant difference in $\mathrm{Gl}$ between the two groups $(t=0.6920, p=0.4913)$. These results are shown in Table 2. 
Table 1: Characteristics of subjects

\begin{tabular}{lcccccccc}
\hline Group & $\begin{array}{c}\text { Gender } \\
(\mathbf{M} / \mathbf{F})\end{array}$ & Age & $\begin{array}{c}\text { Duration } \\
\text { (year) }\end{array}$ & $\begin{array}{c}\text { HCP } \\
\text { (months) }\end{array}$ & $\begin{array}{c}\text { Missing } \\
\text { teeth }\end{array}$ & Smoking & $\begin{array}{c}\text { SBP } \\
(\mathbf{m m H g})\end{array}$ & $\begin{array}{c}\text { DBP } \\
(\mathbf{m m H g})\end{array}$ \\
\hline $\begin{array}{l}\text { Study } \\
(\mathrm{n}=54)\end{array}$ & $29 / 25$ & $58.95 \pm 6.18$ & $7.94 \pm 2.44$ & $10.34 \pm 5.03$ & $3.20 \pm 0.33$ & 12 & $125.54 \pm 13.16$ & $83.37 \pm 9.57$ \\
Control & $31 / 24$ & $60.32 \pm 7.38$ & $7.80 \pm 2.61$ & $11.28 \pm 4.97$ & $3.15 \pm 0.41$ & 11 & $122.76 \pm 12.88$ & $82.56 \pm 8.91$ \\
$(\mathrm{n}=55)$ & & 0.83 & 0.23 & 0.78 & 0.56 & 0.12 & 0.89 & 0.36 \\
$t / X^{2}$ value & 0.12 & 0.41 & 0.82 & 0.44 & 0.58 & 0.73 & 0.38 & 0.72 \\
$p$ value & 0.73 & 0.41 &
\end{tabular}

$H C P=$ History of chronic periodontitis; $S B P=$ Systolic blood pressure; $D B P=$ Diastolic blood pressure

Table 2: BOP, GI and PD of patients (mean \pm SD)

\begin{tabular}{lcccccc}
\hline \multirow{2}{*}{ Group } & \multicolumn{2}{c}{ PD $(\mathbf{m m})$} & \multicolumn{2}{c}{ GI $(\mathbf{m m})$} & \multicolumn{2}{c}{ BOP $(+)$} \\
\cline { 2 - 6 } & $\begin{array}{c}\text { Before } \\
\text { treatment }\end{array}$ & $\begin{array}{c}\text { After } \\
\text { treatment }\end{array}$ & $\begin{array}{c}\text { Before } \\
\text { treatment }\end{array}$ & $\begin{array}{c}\text { After } \\
\text { treatment }\end{array}$ & $\begin{array}{c}\text { Before } \\
\text { treatment }\end{array}$ & $\begin{array}{c}\text { After } \\
\text { treatment }\end{array}$ \\
\hline Study $(\mathrm{n}=54)$ & $5.78 \pm 0.85$ & $4.06 \pm 0.25$ & $1.33 \pm 0.37$ & $0.68 \pm 0.25$ & $54(100.00)$ & $11(20.37)$ \\
Control & $5.69 \pm 0.94$ & $4.23 \pm 0.31^{*}$ & $1.35 \pm 0.36$ & $0.72 \pm 0.23^{*}$ & $55(100.00)$ & $23(41.82)^{*}$ \\
$(\mathrm{n}=55)$ & 0.4168 & 2.5031 & 0.2276 & 0.6920 & - & 3.9380 \\
$t / X^{2}$ value & 0.6782 & 0.0148 & 0.8207 & 0.4913 & - & 0.0472 \\
$P$-value & & & & & \\
\hline
\end{tabular}

$P<0.05$, compared with value before treatment

\section{PLI, CAL and SBI indices}

At week 12 post-treatment, both groups had significant improvements in PLI, CAL and SBI ( $p$ $<0.05$ ), but the study group had much lower PLI, $\mathrm{CAL}$, and $\mathrm{SBI}(0.50 \pm 0.28,3.42 \pm 0.27,1.43 \pm$ 0.26 , respectively) than the control group $(0.84 \pm$ $0.49, p=0.0008 ; 4.35 \pm 0.30, p<0.0001 ; 1.67 \pm$ $0.19, p<0.0001$, respectively). These results are shown in Table 3.

\section{Blood glucose parameters for the patients}

After 12 weeks of treatment, FPG and $\mathrm{HbA} 1 \mathrm{c}$ in the study group $(8.50 \pm 1.31 \mathrm{mmol} / \mathrm{L}$ and $7.33 \pm$ $0.90 \mathrm{mmol} / \mathrm{L}$, respectively) and the control group
$(8.93 \pm 1.20 \mathrm{mmol} / \mathrm{L}$ and $8.42 \pm 1.21 \mathrm{mmol} / \mathrm{L}$, respectively) improved significantly $(p<0.05)$, but there was no significant difference in FPG between both groups ( $t=1.4225, p=0.1595)$. However, HbA1c was significantly lower in the study group than in the control group $(t=4.2360$, $p=0.0001$; Table 4).

\section{Changes in TG, TC and BMl following treatment}

After 12 weeks of treatment, there were no significant improvements in TG, TC and BMI of the study group when the previous and posttreatment values were compared

Table 3: PLI, CAL and SBI indices for the patients (mean \pm SD)

\begin{tabular}{lcccccc}
\hline \multirow{2}{*}{ Group } & \multicolumn{2}{c}{ PLI } & \multicolumn{2}{c}{ Cal $(\mathbf{m m})$} & \multicolumn{2}{c}{ SBI } \\
\cline { 2 - 7 } & $\begin{array}{c}\text { Before } \\
\text { treatment }\end{array}$ & $\begin{array}{c}\text { After } \\
\text { treatment }\end{array}$ & $\begin{array}{c}\text { Before } \\
\text { treatment }\end{array}$ & $\begin{array}{c}\text { After } \\
\text { treatment }\end{array}$ & $\begin{array}{c}\text { Before } \\
\text { treatment }\end{array}$ & $\begin{array}{c}\text { After } \\
\text { treatment }\end{array}$ \\
\hline Study $(\mathrm{n}=54)$ & $1.30 \pm 0.53$ & $0.50 \pm 0.28^{*}$ & $5.47 \pm 0.33$ & $3.42 \pm 0.27$ & $3.40 \pm 0.51$ & $1.43 \pm 0.26$ \\
Control & $1.32 \pm 0.49$ & $0.84 \pm 0.49^{*}$ & $5.50 \pm 0.42$ & $4.35 \pm 0.30^{*}$ & $3.35 \pm 0.69$ & $1.67 \pm 0.19^{*}$ \\
$(\mathrm{n}=55)$ & 0.1628 & 3.5249 & 0.3293 & 13.5222 & 0.3415 & 4.3870 \\
$t$ value & 0.8711 & 0.0008 & 0.7430 & $<0.0001$ & 0.7338 & $<0.0001$ \\
$P$-value & & &
\end{tabular}

${ }^{\star} P<0.05$, compared with value before treatment

Table 4: Blood glucose and HbAlc levels of the patients (mean \pm SD)

\begin{tabular}{lcccc}
\hline \multirow{2}{*}{ Group } & \multicolumn{2}{c}{ FPG (mmol/L) } & \multicolumn{2}{c}{ HbA1c (\%) } \\
\cline { 2 - 5 } & Before treatment & After treatment & Before treatment & After treatment \\
\hline Study $(\mathrm{n}=54)$ & $9.88 \pm 1.75$ & $8.50 \pm 1.31$ & $9.78 \pm 1.85$ & $7.33 \pm 0.90$ \\
Control $(\mathrm{n}=55)$ & $9.83 \pm 1.60$ & $8.93 \pm 1.20$ & $9.60 \pm 2.02$ & $8.42 \pm 1.21^{\star}$ \\
$t$ value & 0.1239 & 1.4225 & 0.3857 & 4.2360 \\
$p$ value & 0.9017 & 0.1595 & 0.7009 & 0.0001 \\
\hline${ }^{*} P<0.05$, rompared with pre-treatment value & &
\end{tabular}


Table 5: Changes in TG, TC and BMI of patients after treatment (mean \pm SD)

\begin{tabular}{|c|c|c|c|c|c|c|}
\hline \multirow[b]{2}{*}{ Group } & \multicolumn{2}{|c|}{$\mathrm{TG}(\mathrm{mmol} / \mathrm{L})$} & \multicolumn{2}{|c|}{$\mathrm{TC}(\mathrm{mmol} / \mathrm{L})$} & \multicolumn{2}{|c|}{ BMI $\left(\mathrm{kg} / \mathrm{m}^{2}\right)$} \\
\hline & $\begin{array}{c}\text { Before } \\
\text { treatment }\end{array}$ & $\begin{array}{c}\text { After } \\
\text { treatment }\end{array}$ & $\begin{array}{c}\text { Before } \\
\text { treatment }\end{array}$ & $\begin{array}{c}\text { After } \\
\text { treatment }\end{array}$ & $\begin{array}{c}\text { Before } \\
\text { treatment }\end{array}$ & Before treatment \\
\hline $\begin{array}{l}\text { Study } \\
(\mathrm{n}=54)\end{array}$ & $2.23 \pm 1.12$ & $1.89 \pm 1.03$ & $5.73 \pm 1.22$ & $5.77 \pm 1.58$ & $28.88 \pm 3.10$ & $28.35 \pm 3.68$ \\
\hline $\begin{array}{l}\text { Control } \\
(n=55)\end{array}$ & $2.45 \pm 1.56$ & $2.10 \pm 0.75$ & $6.04 \pm 1.45$ & $5.92 \pm 1.60$ & $29.05 \pm 4.26$ & $28.86 \pm 3.60$ \\
\hline $\begin{array}{l}t \text { value } \\
P \text {-value }\end{array}$ & $\begin{array}{l}0.6712 \\
0.5044\end{array}$ & $\begin{array}{l}0.9702 \\
0.3354\end{array}$ & $\begin{array}{l}0.9596 \\
0.3407\end{array}$ & $\begin{array}{l}0.3917 \\
0.6965\end{array}$ & $\begin{array}{l}0.1891 \\
0.8506\end{array}$ & $\begin{array}{l}0.5817 \\
0.5627\end{array}$ \\
\hline
\end{tabular}

$(2.23 \pm 1.12 / 1.89 \pm 1.03 \mathrm{mmol} / \mathrm{L}, \quad 5.73 \pm$ $1.22 / 5.77 \pm 1.58 \mathrm{mmol} / \mathrm{L}, 28.88 \pm 3.10 / 28.35 \pm$ $3.60 \mathrm{mmol} / \mathrm{L}$, respectively), and the control group $(2.45 \pm 1.56 / 2.10 \pm 0.75 \mathrm{mmol} / \mathrm{L}, 6.04 \pm$ $1.45 / 5.92 \pm 1.60 \mathrm{mmol} / \mathrm{L}, 29.05 \pm 4.26 / 28.86 \pm$ $3.60 \mathrm{mmol} / \mathrm{L}$, respectively) $(p>0.05)$. Moreover, the differences in TG, TC and BMI between the two groups after 12 weeks of treatment were not significant $(p>0.05$; Table 5$)$.

\section{DISCUSSION}

It is necessary to eliminate pathogenic factors, control plaque attachment and inflammation in the treatment of CP. A range of therapeutic measures used in clinics have been documented [9-12]. These include periodontal non-surgical treatment, medication, surgery, laser therapy and orthodontic therapy [13]. Periodontal non-surgical treatment is the most basic approach to treating CP. It comprises plaque control, scaling, and root planing. Medication may be topical and/or systemic. The common topical medications include periodontal pocket lavage fluid, and gargling with antibiotics. These medications directly reduce plaque by killing pathogenic bacteria that attach to periodontal tissues. Systemic medications contain broad spectrum antibiotics, such as tetracycline and metronidazole, and Chinese materia medica. Minocycline has broader antimicrobial spectrum and it is more widely used in treating CP due to fact that it produces good effect. Surgical strategies include gingival resection and guided periodontal tissue regeneration used for patients with $\mathrm{PD}>5 \mathrm{~mm}$ and positive BOP after 2 3 months of non-surgical treatment [14]. Laser therapy is a major adjuvant therapy used to clear pathogenic bacteria and diseased tissue in the deeper recesses of the periodontal pocket, thereby improving the therapeutic effect of CP [15]. It has been reported that orthodontic treatment controls periodontal inflammation and augments control of blood glucose [16]. Studies on semiconductor laser-assisted minocycline therapy are very few. Therefore, the present study investigated the effect of using semiconductor laser-assisted minocycline therapy for the treatment of $\mathrm{CP}$ patients with T2DM.

Clinically, indices like PLI, CAL and SBI are usually used to assess CP and its treatment [17]. In this study, at week 12 after treatment, both groups had marked improvements in BOP, Gl and $P D$, but the occurrences of $P D$ and BOP in the study group were much less than those of the control group. These results are in agreement with a previous report on decreases in BOP after three months of treatment [18]. In addition, it has been reported that $\mathrm{PLI}$ in patients undergoing semiconductor laser combined with periodontal non-surgical therapy decreased significantly after three months of therapy [19]. In the present study, both groups also had improvements in PLI, CAL and SBI after treatment, but the PLI, $\mathrm{CAL}$ and $\mathrm{SBI}$ of the study group were much lower than those of the control group. This indicates that semiconductor laser-assisted minocycline therapy is very beneficial in treating $\mathrm{CP}$. The possible mechanism involved in this beneficial effect is that semiconductor laser can remove the diseased tissues in periodontal pocket more thoroughly, especially those deeply embedded, thereby preventing the proliferation of attached bacteria under anaerobic environment [20].

In patients with T2DM, vasculopathy may aggravate periodontal pocket hypoxia. The removal of diseased tissues by semiconductor is very important for these patients. Studies have shown that T2DM is positively related to the severity of $\mathrm{CP}$, suggesting that effective treatment of CP can be beneficial to the blood glucose control of T2DM patients [21]. Patients with T2MD are affected by $\mathrm{CP}$, and their increased levels of inflammatory factors enhance insulin resistance [22]. It has been suggested that with treatment, C-creative protein (CRP) in CP patients with T2DM greatly decreases and that the control of the inflammatory responses associated with $\mathrm{CP}$ is helpful to the control of blood glucose in these patients [23]. In this study, the pattern of changes in FPG and $\mathrm{HbA} 1 \mathrm{c}$ in the study group and the control group shows that semiconductor laser-assisted minocycline 
therapy in treating CP was able to control blood glucose, weaken the effect of hyperglycemia on the periodontal tissues, and enhance the therapeutic effect of CP. These findings are in agreement with results obtained in a previous study, in which it was found that treatment of periodontal diseases of DM patients is helpful for the control of blood glucose [24].

It has been suggested that obesity is a risk factor for DM patients, and that abnormal lipid levels can also have adverse effects on CP [25]. In this study, after 12 weeks of treatment, there were no significant improvements in TG, TC and BMI of both groups. Thus, controlling periodontal inflammation did not appear to have any effect on BMI. It is likely that the follow-up period of twelve weeks was too short for any meaningful changes in the patients' BMI. Moreover, there was no comparison between therapeutic effects in patients with various BMls.

\section{CONCLUSION}

The results of this study indicate that semiconductor laser-assisted therapy is capable of greatly enhancing the efficacy of minocycline in treating moderate-to-severe chronic periodontitis in patients with T2DM, via better control of their blood glucose levels. Thus, semiconductor laser-assisted therapy deserves further exploration in the management of chronic periodontitis.

\section{DECLARATIONS}

\section{Conflict of Interest}

No conflict of interest associated with this work.

\section{Contribution of Authors}

We declare that this work was done by the authors named in this article and all liabilities pertaining to claims relating to the content of this article will be borne by the authors, all authors read and approved the manuscript for publication. Tao Hong conceived and designed the study, Ren Le, Zhang Zhe, Li Daxu, Deng Chunni collected and analysed the data, Ren Le $\mathrm{C}$ wrote the manuscript.

\section{REFERENCES}

1. Engebretson SP, Hyman LG, Michalowicz BS. The effect of non-surgical periodontal therapy on hemoglobin A1C levels in persons with type 2 diabetes and chronic periodontitis: a randomized clinical trial. JAMA 2013; 310(23): 2523-2532.
2. Zhang JC. Advance in effect of chronic periodontitis on onset and progress of diabetes. Chin J Stomatol 2013; 48(3): 138-141.

3. Shi ZC, Jiang CM, Xu Y, Sun Y, Periodontology DO. Effects of diode laser on the treatment for moderate to severe chronic periodontitis. Stomatol 2014; 34(04): 245-248.

4. Figueiredo LC, Souza DC, Santos VR, Miranda TS, Feres M, Faveri M, Duarte PM. Full-mouth scaling and root planing in type 2 diabetic subjects: one-year microbiological outcomes. Aust Dent J 2014; 59(4): 490496.

5. Chen DL, Song ZC, Shu R. Research progress of the relationship between chronic periodontitis and type 2 diabetes mellitus. Stomatol 2015; 35(04): 306-309.

6. Xiong JP, Kong YG, Yang X. Clinical study of the correlation of obesity with chronic periodontitis. J Prac Stom 2015; (2): 259-261.

7. Meng HX. Guidelines for the prevention and treatment of periodontitis in China M. People's Medical Publishing House 2015;

8. World Health Organization. Declaration of Helsinki. Br Med J 1996; 313(7070): 1448-1449.

9. $X u F$, Song $Z$. Progress in treatment for chronic periodontitis with diabetes. J Clin Stomatol 2015; 31(03): 184-186.

10. Ma C. Clinical effect and safety for minocycline adjuvant treatment of patients with chronic periodontitis. Chin J Clin Pharmacol 2015; 31(14): 1405-1406.

11. Shirakashi DJ, Leal RP, Colombo NH, Chiba FY, Garbin $C A$, Jardim EG JR, Antoniali C, Sumida DH. Maternal periodontal disease in rats decreases insulin sensitivity and insulin signaling in adult offspring. J Periodontol 2013; 84(3): 407-414.

12. Li Z, Sha YQ, Zhu L, Zhang BX, Xu JL. Effects of dental health awareness and behaviours on the glycemic metabolic characteristics and periodontal disease of patients with type 2 diabetic. J Peking Uni (Health Sciences) 2013; 45(6): 979-983.

13. Aimetti M. Nonsurgical periodontal treatment. Int J Esthet Dent. 2014; 9(2): 251-267.

14. Mouchref Hamasni F, El Hajj F, Abdallah R. Single Sitting Surgical Treatment of Generalized Aggressive Periodontitis Using GTR Technique and Immediate Implant Placement with 10-Year Follow-Up. Case Rep Dent. 2018 23;2018: 6194042.

15. Gregg DM, Suzuki JB.More on Laser Treatment of Periodontal Disease.J Calif Dent Assoc. 2016 Sep;44(9): 534-535.

16. Yang J. Effect of Orthodontic Treatment on Blood Sugar Lever of Periodontitis with Type 2 Diabetes Mellitus. J Oral Sci Res 2012; 28(2): 162-164.

17. Duarte PM, Bezerra JP, Miranda TS, Feres $M$, Chambrone L, Shaddox LM. Local levels of inflammatory mediators in uncontrolled type 2 diabetic subjects with chronic periodontitis. J Clin Periodontol 2014; 41(1): 11-18. 
18. Xu HB, Wu S. Clinical Observation of Minocycline in the Treatment of Moderate and Severe Chronic Periodontitis Complicated with Type 2 Diabetes. Chin Pharm 2017; 28(23): 3254-3257.

19. Cao YF, Zhang L, Zhang R, Zhou Y, Han JL. The effect of semiconductor laser combined with periodontal treatment on periodontitis with diabetes. Ningxia Med $J$ 2017; (12): 1-7.

20. Chen L, Su Y, Ni J, Luo W, Xuan DY, Zhang J. Effects of non-surgical periodontal treatment on clinical response, serum inflammatory parameters, and metabolic control of type 2 diabetes patients with moderate to severe periodontitis. West Chin J Stomatol 2014; 23(1): 66-70.

21. Timonen $P$, Saxlin $T$, Knuuttila $M$, Suominen $A L$, Jula $A$, Tervonen $T$, Ylöstalo $P$. Role of insulin sensitivity and beta cell function in the development of periodontal disease in adults without diabetes. J Clin Periodontol 2013; 40(12): 1079-1086.
22. Gay IC, Tran DT, Cavender AC, Weltman R, Chang J, Luckenbach E, Tribble GD. The effect of periodontal therapy on glycaemic control in a Hispanic population with type 2 diabetes: a randomized controlled trial. $J$ Clin Periodontol 2014; 41(7): 673-680.

23. Mohan M, Jhingran R, Bains VK, Gupta V, Madan R, Rizvi I, Mani K. Impact of scaling and root planing on $C$ reactive protein levels in gingival crevicular fluid and serum in chronic periodontitis patients with or without diabetes mellitus. J Periodontal Implant Sci 2014; 44(4): 158-168.

24. Engebretson S, Kocher T. Evidence that periodontal treatment improves diabetes outcomes: a systematic review and meta-analysis. J Clin Periodontol 2013; 40(14): S153-S163.

25. Chaffee BW, Weston SJ. Association between chronic periodontal disease and obesity: a systematic review and meta-analysis. J Periodontol 2010; 81(12): 17081724. 